\title{
IMPLEMENTASI KURIKULUM 2013 DALAM PEMBELAJARAN IPS TERPADU DI SMP NEGERI KOTA SINGKAWANG
}

\author{
Emusti Rivasintha Marjito ${ }^{1}$, Karel Juniardi ${ }^{2}$ \\ ${ }^{1,2}$ Program Studi Pendidikan Sejarah \\ Fakultas Ilmu Pendidikan dan Pengetahuan Sosial IKIP PGRI Pontianak \\ Jalan Ampera Nomor 88 Pontianak - 78116, Telepon (0561) 748219 Fax. (0561) 589855 \\ Alamat e-mail: ${ }^{1}$ sintha_160111@yahoo.co.id
}

\begin{abstract}
Abstrak
Tujuan penelitian adalah untuk memaparkan perencanaan dan pelaksanaan pembelajaran IPS Terpadu dalam Kurikulum 2013 di SMP Negeri Kota Singkawang. Penelitian ini menggunakan metode penelitian deskriptif dengan pendekatan kualitatif dan bentuk penelitiannya adalah studi kasus. Teknik pengumpulan data yang digunakan adalah teknik observasi langsung, teknik komunikasi langsung, dan studi dokumenter. Dari hasil pengolahan data dapat disimpulkan bahwa perencanaan pembelajaran IPS Terpadu di SMP Negeri Kota Singkawang sudah baik karena guru sebagian besar sudah mengetahui dan memahami Permendikbud tentang Kerangka Dasar dan Struktur Kurikulum 2013 SMP/MTs, dan memahami Permendikbud tentang Standar Isi Pendidikan Dasar dan Menengah, serta memahami dengan baik Permendikbud tentang Standar Proses Pendidikan Dasar dan Menengah. Pelaksanaan pembelajaran IPS Terpadu di SMP Negeri Kota Singkawang sudah baik karena mayoritas guru IPS sudah menyusun Rencana Pelaksanaan Pembelajaran, pelaksanaan proses pembelajaran yang dilakukan guru terhadap siswa, serta telah melakukan tindak lanjut proses pembelajaran dengan Pendekatan Saintifik Ilmiah.
\end{abstract}

Kata Kunci: Kurikulum 2013; pembelajaran IPS Terpadu; SMP Negeri di Singkawang;

\begin{abstract}
The purpose of the study was to describe the planning and implementation of IPS Terpadu learning in the 2013 Curriculum at SMP Negeri in Singkawang. This study uses descriptive research methods with qualitative approaches and the form of research is case studies. Data collection techniques used are direct observation techniques, direct communication techniques, and documentary studies. From the results of data processing, it can be concluded that the planning of IPS Terpadu learning in SMP Negeri Singkawang is already good because most teachers already know and understand "Kerangka Dasar dan Struktur, Standar Isi and Standar Proses" of 2013 Curriculum. The implementation of IPS Terpadu learning in SMP Negeri Singkawang has been good because the majority of IPS teachers have prepared Learning Implementation Plans, implemented the learning process conducted by teachers to students, and has followed up the learning process with Scientific Scientific Approach.
\end{abstract}

Keywords: 2013 Curriculum; IPS Terpadu learning; SMP Negeri in Singkawang;

\section{PENDAHULUAN}

Kurikulum adalah perangkat mata pelajaran dan program pendidikan yang diberikan oleh suatu lembaga penyelenggara pendidikan yang berisi rancangan 
pelajaran yang akan diberikan kepada peserta pelajaran dalam satu periode jenjang pendidikan. Penyusunan perangkat mata pelajaran ini disesuaikan dengan keadaan dan kemampuan setiap jenjang pendidikan dalam penyelenggaraan pendidikan tersebut serta kebutuhan lapangan kerja.

Kurikulum menurut UU Sisdiknas, (UU No 20/2003), ialah seperangkat rencana dan pengaturan mengenai tujuan, isi dan bahan pelajaran serta cara yang digunakan sebagai pedoman penyelenggaraan kegiatan pembelajaran untuk mencapai tujuan pendidikan tertentu. Kurikulum 2013 mengembangkan pengalaman belajar yang memberikan kesempatan bagi peserta didik untuk menguasai kopetensi yang yang diperlukan bagi kehidupan dimasa kini dan masa depan. Kurikulum 2013 di susun dengan maksud antara lain untuk mengembangkan potensi peserta didik menjadi kemampuan dalam berfikir reflektif dalam menyelesaikan masalah sosial di masyarakat. Kurikulum 2013 dikembangkan dengan penyempurnaan pola pikir dari pembelajaran pasif menjadi pembelajaran kritis, pola pelajaran yang semula berpusat pada guru menjadi pelajaran yang berpusat pada peserta didik dan yang semula satu arah menjadi pembelajaran Interaktif.

Sekolah sebagai salah satu lembaga pendidikan formal merupakan lingkungan hidup kedua sesudah rumah di mana anak didik sekian jam setiap saat setiap hari mengisi hidupnya. Dalam konteks kehidupan berbangsa dan bernegaran pendidikan penting bagi kita. Melalui pendidikan kita dapat menemukan jati diri kita sebagai manusia yang sesungguhnya. Pendidikan dirancang untuk membentuk manusia yang cerdas, berkepribadian, bertanggung jawab, berakhlak mulia, memiliki wawasan yang luas, serta beriman dan bertaqwa Allah Swt.

Menurut Suryani dan Agung, (2012:1) pembelajaran pada dasarnya adalah suatu kegitan yang bernilai edukatif. Nilai edukatif mewarnai interaksi yang terjadi antara guru dan peserta didik. Interaksi bernilai edukatif dikarenakan pembelajaran yang dilakukan, diarahkan untuk mencapai tujuan yang telah dirumuskan sebelumnya. Pembelajaran IPS yang dilakukan baik pada pendidikan tinggi tidak menekankan pada aspek teoritis keilmuannya, tetapi aspek praktis dalam 
mempelajari, dalam menkaji, gejala dan masalah sosial masyarakat, yang bobot dan keluasaannya disesuaikan dengan jenjang pendidikan masing-masing.

Guru IPS Terpadu dituntut untuk mampu memperaktekan kurikulum 2013 kepada siswa khususnya yang berkaitan dengan materi pelajaran dan nilai-nilai karakter pada siswa karena kedua hal tersebut bermuara pada hasil belajar sebagai tujuan dari suatu pendidikan. Khususnya pada mata pelajaran IPS Terpadu, dimana materi pelajaran dan aplikasi nilai-nilai yang terkandung dalam mata pelajaran tersebut senantiasa berkembang sejalan dengan perkembangan masyarakatnya.

\section{METODE}

Metode yang digunakan dalam penelitian ini adalah metode deskriptif kualititatif. metode deskriptif merupakan prosedur pemecahan masalah yang memandu peneliti untuk mengeksplorasi dan atau memotret situasi sosial yang akan diteliti secara menyeluruh, luas dan mendalam. Dipilih metode deskriptif dalam penelitian ini dianggap tepat untuk mengungkapkan hal-hal yang terjadi di lapangan sebagaimana apa adanya. Adapun bentuk penelitian yang digunakan dalam penelitian ini adalah studi kasus, berdasarkan pertimbangan bahwa tujuan studi kasus adalah untuk memberikan gambaran secara mendetail tentang latar belakang, sifa-sifat serta karakter-karakter yang khas dari kasus.

Teknik pengumpulan data yang peneliti gunakan adalah 3 (tiga) teknik pengumpulan data, yaitu teknik komunikasi langsung, teknik observasi langsung, dan teknik studi dokumenter/ babliografhis. Untuk mendapatkan data yang akurat dilapangan dalam penelitian ini akan menetapkan beberapa alat sebagai pengumpulan data adalah panduan abservasi, panduan wawancara dan analisis dokumentasi. Data-data yang telah dikumpulkan dari sumber data tidak semuanya akurat, sehingga dibutuhkan suatu teknik tepat untuk menguji keapsahan data. Untuk menguji data dalam penelitian ini digunakan teknik triangulasi. Teknik tringulasi berarti peneliti menggunakan teknik pengumpulan data yang berbedabeda untuk mendapatkan data dari sumber yang sama, namun dalam penelitian ini hanya digunakan tringulasi data dan tringulasi metode. 
Teknik analisis data yang digunakan dalam penelitian ini adalah analisis model interkatif (interactive model of analysis). Menurut sugiyono (2011:338) dalam model interaktif terdapat tiga komponen analisis, yaitu reduksi data, sajian data dan penarikan kesimpulan, dilakukan dengan bentuk interaktif dengan proses pengumpulan data (data collecting).

\section{HASIL DAN PEMBAHASAN}

\section{Perencanaan pembelajaran IPS Terpadu Dalam Kurikulum 2013}

Kurikulum merupakan instrumen yang membantu praktisi pendidikan untuk memenuhi kebutuhan peserta didik dan kebutuhan masyarakat. Pengembangan kurikulum merupakan alat untuk membantu guru melakukan tugas mengajarnya dan memenuhi kebutuhan masyarakat. Oleh karena itu, dalam rangka pelaksanaan Kurikulum 2013 diperlukan adanya pemahaman terlebih dahulu terkait hal-hal yang mengenai perencanaan pembelajaran kurikulum 2013 sebagai bentuk kesiapan guru antara lain memahami pemendikbud yang berkaitan dengan Kerangka Dasar dan Struktur Kurikulum 2013 Sekolah Menengah Pertama/SMP.

Memahami Permendikbud tentang Kerangka Dasar dan Struktur Kurikulum 2013 Sekolah Menengah Pertama/SMP Negeri yang tercantum dalam Permendikbud Nomor 68 Tahun 2013, Permendikbud tentang Standar Isi Pendidikan Dasar dan Menegah yang tercantum dalam Permendikbud Nomor 21 Tahun 2016, serta Permendikbud tantang Standar Proses Pendidikan Dasar dan Menengah yang tercantum dalam Permendikbud Nomor 22 Tahun 2016. Hal ini menunjukkan bahwa pemahaman dalam proses pendidikan sudah dipahami dengan baik oleh guru.

Guru sudah dapat menyusun Rencana Pelaksanaan Pembelajaran dengan Pendekatan Saintifik Ilmiah. Setiap guru pada satuan pendidikan berkewajiban untuk menyusun RPP secara lengkap dan sistematis agar proses belajar mengajar dapat berjalan secara interaktif, inspiratif, menyenangkan, menantang dan memotivasi peserta didik untuk dapat berpartisipasi aktif. RPP adalah rencana yang dirancang oleh guru yang menggambarkan prosedur pembelajaran untuk mencapai 
satu kompetensi dasar yang meliputi satu atau beberapa indikator untuk satu atau beberapa kali pertemuan.

Hasil observasi tentang kemampuan guru dalam menyusun RPP diperoleh informasi sebagi berikut : 1) Guru IPS Terpadu telah merumuskan indikator, 2) telah merumuskan tujuan pembelajaran, namun belum merumuskan unsur menciptakan karya, 3) telah merumuskan materi pelajaran, 4) telah merumuskan media belajar, 5) telah merumuskan metode pembelajaran, serta 6) telah merumuskan rencana kegiatan pembelajaran dan menunjukkan bahwa pemahaman guru IPS menunjukkan bahwa perencanaan pembelajaran terutama dalam hal Menyusun Rencana Pelaksanaan Pembelajaran sudah menggunakan Pendekatan Saintifik Ilmiah.

Bentuk kesiapan guru dalam penerapan Kurikulum 2013 adalah menguasai dan memahami Permendikbud yang terkait dengan Kerangka Dasar dan Struktur, Standar Isi dan Standar Proses Kurikulum 2013. Temuan penelitian menunjukkan bahwa kesiapan guru IPS di SMP Negeri Kota Singkawang sudah baik. Pemahaman yang baik ini menunjukkan bahwa guru IPS sudah siap dalam menerapkan Kurikulum 2013. Hal ini dikemukakan oleh Indratno (2013:4) yang menyatakan bahwa : "menguasai kebijakan pemerintah yang terkait dengan kerangka kurikulum 2013 merupakan salah satu indikator bentuk kesiapan dan partisipasi guru untuk mengimplementasikan Kurikulum 2013”.

Pada hakikatnya bila suatu kegiatan direncanakan terlebih dahulu maka tujuan dari kegiatan tersebut lebih terarah dan lebih berhasil. Itulah sebabnya seorang guru, sebelum mengajar hendaknya merencanakan program pengajaran, membuat persiapan pengajaran yang hendak diberikan kepada siswa. Menurut Suryosubroto (2009:23) "perencanaan itu dapat bermanfaat bagi guru sebagai kontrol terhadap diri sendiri agar dapat memperbaiki cara pengajarannya”.

\section{Pelaksanaan pembelajaran IPS Terpadu dalam Kurikulum 2013}

Penerapan Kurikulum 2013 pada proses pembelajaran satuan pendidikan diselenggarakan secara interaktif, inspiratif menyenangkan, menantang, memotivasi peserta didik unuk berpartisipasi aktif, serta memberikan ruang yang 
cukup untuk mengembangkan potensi peserta didik. Dalam standar proses yang mencakup perencanaan proses pembelajaran, pelaksanaan proses pembelajaran, penilaian hasil belajar, dan pengawasan proses pembelajaran (Permendikbud Nomor 22 Tahun 2016).

Pelaksannan kurikulam 2013 dalam pembelajaran dalam IPS Terpadu menyangkut penyusunan Rancana Pelaksaan Pembelajaraan (RPP) yang mengharuskan menggunakan pendekatan saintifik,pelaksanaan pembelajaran, tindakan lanjut proses Pembelajaraan serta evaluasi hasil belajar. Peningkatan yang terjadi dalam mutu pendidikan akan tercapai apabila proses pembelajaran yang berlangsung di kelas benar-benar efektif dan menyenangkan untuk mencapai kemampuan pengetahuan, sikap dan keterampilan yang diharapkan. Oleh karena itu, sebagai guru perlu melaksanakan proses pembelajaran yang sesuai dengan perencanaan yang disusun dan berlangsung efektif.

Berdasarkan temuan penelitian menunjukkan guru telah menyusun Rencana Pelaksanaan Pembelajaran (RPP) dan melaksanakan pembelajaran yang menerapkan pendekatan saitifik ilmiah yang menjadi ciri khas pendekatan pembelajaran dalam Kurikulum 2013. Sedangkan tindak lanjut proses pembelajaran dilaksanakan dengan memberikan arahan kegiatan belajar selanjutnya, latihan soal, remedial, dan tugas pengayaan. Ini menjadi bukti bahwa kesiapan guru IPS dalam hal proses pembelajaran IPS menerapkan Kurikulum 2013 sudah dilaksanakan dengan baik.

Hal ini sejalan dengan pendapat fadlillah (2014:175) yang menyatakan : "Pendekatan yang digunakan dalam pembelajaran Kurikulum 2013 adalah pendekatan scientifc yang dilakukan melalui proses alamiah". Karena Kurikulum 2013 menuntut guru untuk melakukan pembelajaraan berbasis pendekatan sains, maka kompetensi pedagogik guru sangat diperlukan untuk pengembangan proses pembelajaran yang dilakukan di dalam kelas.

Dalam proses pembelajaran menggunakan kurikulum 2013, peserta didik adalah subjek yang memiliki kemampuan secara aktif mencari, mengolah, mengkonstruksikan dan menggunakan pengetahuan (Abdul Majid, 2004:98). Pembelajaran tidak lagi berpusat kepada guru melainkan kepada anak didik. Peran 
guru yaitu merancang pembelajaran, mengenali tingkat pengetahuan individu anak didik dan memotivasi peserta didik untuk meningkatkan keberhasilan anak didik dan menyiapkan kondisi belajar yang menyenangkan. Berdasarkan pembahasan di atas, dapat disimpulkan bahwa pelaksanaan kurikulum 2013 pada mata pembelajaran IPS sudah terlaksana dengan baik.

Implementasi Kurikulum 2013 diharapkan dapat menghasilkan insan yang produktif, kreatif, dan inovatif. Mulyasa (2014:131) "Keberhasilan dari Kurikulum 2013 dalam pembentukan kompetensi dan karakter peserta didik dapat dilihat dari segi proses dan dari segi hasil. Dalam hal segi proses, pembentukan kompetensi dan karakter dikatakan berhasil dan berkualitas apabila seluruhnya atau setidaknya $75 \%$ terlihat secara aktif, baik fisik, mental maupun sosial dalam proses pembelajaran, dapat menunjukkan kegairahan belajar yang tinggi, semangat belajar yang besar dan rasa percaya pada diri sendiri. Selain itu dari segi hasil dapat dilihat proses pembentukan kompetensi dan karakter yangg dapat dikatakan berhasil apabila terjadi perubahan perilaku yang mengarah positif pada diri peserta didik seluruhnya atau setidaknya $75 \%$.

Pada dasarnya dalam mengimplementasi kurikulum 2013 dalam pembelajaran guru menemukan faktor penghambat atau kendala sehingga kegiatan pembelajaran belum dapat terlaksana secara optimal. Karena adanya faktor penghambat atau kendala baik itu yang bersumber dari lembaga pendidikan yang bertujuan untuk mewujudkan cita-cita pendidikan nasional, serta guru sebagai pelaksana kegiatan pembelajaran maupun dari siswa itu sendiri sebagai objek pembelajaran, faktor-faktor tersebut mengakibatkan pelaksanaan kegiatan pembelajaran belum mampu mencapai tujuan yang optimal.

Faktor-faktor penghambat yang disebutkan di atas relevan dengan yang dihadapi guru saat pelaksanaan pembelajaran IPS dengan menggunakan kurikulum 2013, hambatan dalam pembelajaran IPS antara lain: (1) hambatan keahlian dan akademik, (2) hambatan fasilitas pendidikan, (3) hambatan mutu buku pendidikan, (4) dan hambatan administrasi manejemen.

\section{SIMPULAN}


Perencanaan pembelajaran IPS Terpadu dalam kurikulum 2013 di SMP Negeri Kota Singkawang sudah baik karena guru sudah memahami Permendikbud tentang Kerangka Dasar dan Struktrur Kurikulum 2013 SMP/MTs, dan guru sudah memahami Permendikbud tentang Standar Isi Pendidikan Dasar dan Menengah. Pelaksanaan pembelajaran IPS Terpadu dalam kurikulum 2013 di SMP Negeri Kota Singkawang sudah baik baik hal ini dikarenakan mayoritas guru IPS sudah menyusun Rencana Pelaksanaan Pembelajaran dengan Pendekatan Saintifik Ilmiah, dan pelaksanaan proses pembelajaran yang dilakukan guru terhadap siswa, serta telah melakukan tindak lanjut proses pembelajaran.

Proses pembelajran IPS dibagi menjadi tiga kegiatan yaitu kegiatan pendahuluan, inti, dan penutup. Pada kegiatan pendahuluan, guru mengucapkan salam dan menyapa seluruh murid. Kemudian guru menyuapkan alat yang akan digunakan untuk media pembelajaran dibantu oleh beberapa siswa.Persiapan ini lah yang menyita sedikit waktu yang telah ditentukan. Selain itu guru melanjutkan ke kegiatan inti pembelajaran yaitu guru sedikit menjelaskan kepada siswa tantang materi yang akan diajarkan. Setelah guru menjelaskan, kemudian siswa dipersilahkan mengadakan sesi tanya jawab untuk menambah pemahaman siswa mengenai materi yang disampaikan. Guru sangat menguasai materi IPS yang diajarkan.

\section{DAFTAR PUSTAKA}

A.M., Sardiman. (2010) Interaksi dan Motivasi Belajar Mengajar, Jakarta: PT. Raja Grafindo Persada.

Amin, H.. (2011) Pendidikan Karakter Anak Bangsa, Jakarta: Baduose Media.

Arends, R I. (2000) Learning To Teach, New York: McGraw Hill Companies.

Arikunto. S. (2004) Prosedur Penelitian, Suatu Pendekatan Praktik, Jakarta: Rineka Cipta.

Baeley, D.K (1982), Methods of Social Research, New York:A Devision of Mac Millan Publishing Co. Inc.

Colin, R. (2000) Cara Belajar Abad 21, Jakarta: Nuansa Cendikiawan. 
Darmadi, H. (2011) Metode Penelitian Pendidikan, Bandung: Alfabeta.

Daryanto (2009) Panduan Proses Pembelajaran Kreatif dan Inovatif, Jakarta: Publisher.

Hamalik, O. (1990). Pengembangan Kurikulum: Dasar-dasar dan Perkembangannya. Bandung: Mandar Maju.

Hasan, S.H. (1988). Evaluasi Kurikulum. Jakarta: P2LPTK.

Kaber, A. (1988). Pengembangan Kurikulum. Jakarta: P2LPTK.

Khan, D. Yahya. (2010) Pendidikan Karakter Berbasis Potensi Diri. Mendongkrak Kualitas Pendidikan. Yogyakarta Publishing.

Nasution, S. (2005). Asas-Asas Kurikulum. Jakarta: Bumi Aksara.

Rianto, Y. ( 2001 ), Metodelogi penelitian pendidikan, Surabaya: SIC.

Sugiyono. (2013), Metode Penelitian Pendidikan, Bandung: Alfabeta.

Surjadi, A. (2012) Membuat Siswa Aktif Belajar, Bandung: Mandar Maju.

Syadih, S. Nana. (1997). Pengembangan Kurikulum, Teori dan Praktek. Bandung: Rosdakarya. 